\title{
The Electoral Campaign on Television
}

Communication Strategies and Models of Democracy

Florence Brisset-Foucault

\section{(2) OpenEdition}

Journals

Electronic version

URL: https://journals.openedition.org/eastafrica/696

DOI: $10.4000 /$ eastafrica. 696

ISSN: 2790-1076

Publisher

IFRA - Institut Français de Recherche en Afrique

\section{Printed version}

Date of publication: 1 April 2008

Number of pages: 109-149

ISSN: 2071-7245

\section{Electronic reference}

Florence Brisset-Foucault, "The Electoral Campaign on Television", Les Cahiers d'Afrique de l'Est / The East African Review [Online], 38 | 2008, Online since 19 July 2019, connection on 09 December 2021. URL: http://journals.openedition.org/eastafrica/696 ; DOI: https://doi.org/10.4000/eastafrica.696

This text was automatically generated on 9 December 2021

Les Cahiers d'Afrique de l'Est / The East African Review 


\title{
The Electoral Campaign on Television
}

\author{
Communication Strategies and Models of Democracy
}

Florence Brisset-Foucault

1 Since the 2002 alternation, the audiovisual sector in Kenya experienced an impressive expansion resulting from political liberalization and economic growth. The vitality of publicity and the presence of a vibrant middle class gave the Kenyan media sector a specific status on the continent. Television viewers had eight local channels at their disposal, which ran a mixture of English and Swahili programmes, a regional station based in Tanzania (East Africa TV, which is largely music-based), cable and satellite TV, as well as American and British (CNN, BBC) news broadcasts. The two stations attracting the largest audiences are Nation TV (NTV) and Kenya Television Network (KTN). ${ }^{1}$ These are followed by Kenya Broadcasting Corporation (KBC, the public network) and Citizen TV, owned by Samuel Macharia, a close friend of Mwai Kibaki. ${ }^{2}$

2 The 2007 electoral campaign was held under tense conditions. There was some violence, and generally, fears concerning the reaction of the defeated candidate punctuated public debate with increasing anxiety. In other respects, in their mobilization speeches, some candidates resorted to an ethnic tone. Despite all this, through television broadcasts, the campaign could appear to be a model, feeding the image of "the continent's window into democracy," that liked to highlight Kenyans and the idea of "normalcy" or of a "democratic routine" of a country in alternation.

3 The weeks before the elections experienced exponential growth in political programming on both TV and radio, with the setting up of political analysis editorial meetings, daily reports of the different political meetings on news programmes (almost completely focusing on the campaigns) and an impressive mobilization of news features, particularly on voting day with the deployment of a network of correspondents in all voting stations throughout the country.

4 The season also came with a flurry of political shows interviewing Kenyan citizens by telephone, text messages (SMS) ${ }^{3}$, and also directly in the studios. These broadcasts, having attained growing visibility on Kenyan television, especially since the 
constitutional referendum of 2005, acquired a legitimate dimension. Bearing witness to this are the resultant polemics on the holding of a live debate between the three main presidential candidates. A show titled 'The Grand Rumble' was to be broadcast by the private channel KTN, in partnership with BBC on 12 December, Jamhuri Day. Raila Odinga declared his willingness to participate and in a press conference held on 10 December, he publicly challenged Mwai Kibaki to participate. The latter has traditionally been rather reticent in the media. Due to the media's growing influence, different strategies emerged within Kenyan politics-Raila Odinga attempted to subvert the structure by imposing new rules of political communication. He persisted in a credible argument, presenting the outgoing president as belonging to a bygone political era, considering that M. Kibaki did not want to submit to a "public examination". ${ }^{4}$ Eventually, Raila also declined the invitation to the debate, saying that it would not be worthwhile to only face Kalonzo Musyoka, the "third man" in the election. In the end, the debate was cancelled.

Despite the 2007 election having displayed an impressive use of political communication strategies, ${ }^{5}$ one must reckon with difficult trends which have existed since 2002, with the major stage being the referendum campaign of 2005. This latter experienced a mobilisation of media owners, who organised two editions of an interactive talk-show aimed at clarifying the stakes of the constitutional reform. This show, The Big Debate, produced by the Media Owners Association (MOA), was simultaneously broadcast on all Kenyan TV channels. It was a means for journalist to publicly display their impartiality in a situation where they had been heavily criticized. ${ }^{6}$ The talk-show was also an important precedent in the structuring of a political communication sphere and the expertise of certain journalists (Julie Gichuru, Louis Otieno, Wachira Waruru...) in the production and presentation of this type of broadcast.

6 Three shows will be discussed in detail here-Debate 07, screened on KTN, Agenda Kenya on NTV, and Citizen TV's Louis Otieno Live on the Road. These shows were viewed from the studios of the TV stations during fieldwork carried out in December 2007, in the four weeks preceding the elections. The programmes were chosen due to their popularity and were aired at peak hours, thus capturing large audiences. The three also had different profiles, with two shows being sponsored by characteristically different NGOs. Louis Otieno... was sponsored by a Dutch foundation, Media Focus on Africa while Agenda Kenya was funded by Medeva, a Kenyan NGO. Debate 07 was aired during the campaign period while Louis Otieno.was a mobile show, going across the eight provinces of Kenya. These were weekly programmes, lasting between 40 to 90 minutes. They were mostly in English, but contributions in Kiswahili also abounded. The shows were built around four or five guest speakers in a forum, before a public of 15 to 150 persons, depending on the show. A moderator led the discussions.

7 The viewing of these shows led to an interrogation of the political models presented and promoted on Kenyan TV. Which of these would fade away to different citizenship, leadership and national community models? How would the limits of what would be termed unspeakable be defined in the public arena? Before an analysis of these models, one must consider the most autonomous sphere of political communication in Kenya, encompassing journalists, politicians, academics, NGOs and international donors. Indeed, these broadcasts were the result of a voluntary collaboration between these different actors, all involved in the electoral campaign. The idea was then to submit 
these models to discussions and to public profiles in order to position and analyse the ideal of citizenship projected in these shows.

\section{Political communication in Kenya: professionalisation, extroversion and autonomy}

8 The "field" according to Bourdieu supposes a much more precise limitation than what currently characterises political communication in Kenya. However, it is a useful notion as it allows an understanding the dynamics of how reproduction stakes and autonomy are created in related fields: academic, journalistic, political and development. ${ }^{7}$ The idea is therefore to show how a professional and political communication sector is structured in Kenya. What position does it take and what are the strength relationships within it? How does each of these actors attempt to preserve their autonomy or to dominate the others in order to pursue their own economic interests and to impose a specific interpretation of the political situation? ${ }^{8}$

\section{The spread of international models and donor involvement}

Extroversion plays an important role in the accumulation of symbolic and financial capital required for a restructuring of the political communication sector. It allows a spread of media models from the North, circulates funding and personnel, and modifies strength relationships on the ground.

\section{Strong presence of NGOs and international donors}

10 The works of Nicolas Guilhot on the influence of the principal social science foundations are clear on the analysis of relationships between fund donors and the African media. According to N. Guilhot, donors must "impose principles conforming to specific interests under an objective and universal form" as universal training principles for the ruling elite. Journalism, with its "universal" rules of a professional code of ethics and impartiality principles-particularly in election periods-and thus its appearance of "objectivity" free from ideology, is in this sense a good base for symbolic exportation.

11 According to Dezalay and Garth, "structural homology" between the North and the South, and the success of symbolic import-export ${ }^{10}$ is visible in Kenya through a meeting of the activities of the high priests of good governance and the values that Kenyan mainstream journalists would like to incarnate within their political space (partisan neutrality, detribalisation and moralisation of political life, denouncing corruption, political and economic liberalism). Furthermore, journalists embody a consensual ideal of democratisation. These factors partly explain the access of the Kenyan media to the NGOs. The meeting between converging economic interests explains the rest.

Some of the most popular talk-shows are sponsored by NGOs that specialise in media production. ${ }^{11}$ This sponsorship takes several forms: the delivery of a complete TV programme to a station, with the production having been completed by the NGO (the filming is done outside the station, the guest speakers and public chosen by the NGO, the costs covered, and programme moderated not by a journalist but by an employee of 
the NGO). This was the case with Agenda Kenya, produced by Medeva, an NGO agitating for a greater allocation of local programmes in the media schedules. Medeva is headed by two British former journalists of the BBC. It is funded by the Ford Foundation, the Open Society Institute, the German Cooperation and also receives funds from advertising.

The second option is what can be referred to as "vampirisation" of a pre-existing broadcast, generally one that had high popularity. This is true for Louis Otieno Live, sponsored between October and December by the Dutch Foundation Media Focus on Africa, mostly from the UNDP "elections" fund. Media Focus paid Citizen TV Ksh 1 million $(€ 10,000)$ per broadcast, to cover the costs of production, and used the programme as a tool for civic education. The NGO also modified some formal aspects of the programme. This sponsorship actually made if possible for Louis Otieno Live to go on the road to eight Kenyan provinces, with local residents and civil society protagonists as the studio audience and forum speakers. This case in particular caused conflict between the NGO and the journalists who wanted to maintain a level of editorial autonomy.

14 Several issues should be emphasized in an analysis of sponsored television broadcasts. If it is to be captured in a global dependence framework, the example of the Kenyan media demands that to a certain extent, the idea of unilateral dependence and an understanding of the unequal strength between donors from the North and the African media, be put into perspective, particularly in an electoral period. Indeed, for an NGO like Media Focus, at this particular moment all stakes were to position itself as an undeniable actor in the political debate, with influence on defining the discussions and the agenda. This immediately justified the monies it received from UNDP and from their other donors but equally conferred some credibility on the media and experts that they sought to attract. The organisation had to position itself in a competitive electoral education field. Some journalists have understood this very well as they play off this competitiveness and dependence on NGOs. ${ }^{12}$ In the electoral context, the market becomes more competitive as new actors emerge and as special funds are released by donors. One must also take into account the good economic health of the media in Kenya ${ }^{13}$ (this differs from other African countries where the media can develop a great dependence on financial donors). These NGOs, whose success in creating projects is partially based on the inequalities of power relationships with local actors, find themselves in a more difficult position in Kenya than elsewhere on the continent.

15 This loss of editorial autonomy resulting from fully-loaded programmes produced externally, if true, must furthermore be routinely replaced in the African audiovisual sector, which imports a huge amount of foreign programmes (from South American soap operas to German cultural broadcasts, BBC and VOA newsflashes...).

Moreover, in the British audiovisual scene, more so in the French journalistic tradition, $\mathrm{TV}$ and radio programmes are often produced commercially, and then bought by the stations. A case in point is Question Time on the BBC, produced by Mentorn, from which Agenda Kenya drew inspiration. This context explains the autonomy given to Medeva by NTV.

17 Despite this, a form of dependence exists: the Kenyan media seek scheduling and local programming. ${ }^{14}$ They also need editorial innovation which allows them to remain competitive although they may not necessarily have the means. These types of 
broadcast define the identity of the station, place the media as undeniable actors in the political debate and allow them to put forward an "impartiality"-this is key in a station like Citizen, whose covering of the campaign was highly favourable to the outgoing president. Turning to NGOs to fund this type of "product" represents an important choice in terms of image and autonomy, since this allows them to be independent of patronage from politicians and large commercial entreprises ${ }^{15}$. The struggle for editorial autonomy led by some journalists against these donors must be taken into account following a broader analysis on issues of management and dependence. The idea for these actors is to attract donors from the North while demonstrating a need and affirming their autonomy at the same time.

The contract between Media Focus and Citizen TV was based on a "shared editorial control" clause. The sharing of tasks was thus carried out from day to day between the two organizations, which created conflict between the donor and the station until the contract was ended. ${ }^{16}$ Media Focus, in accordance with its objectives and those of the UNDP, sought to put forward some values (partisan equilibrium, room for consultants) and certain themes (leadership, corruption, youth, gender), through pre-defined topics and guests. This interference was not appreciated by some journalists at Citizen, who went on to question the relevance of the choices made by Media Focus. ${ }^{17}$ The disagreements were mainly on the amount of time to allot debates in the different places visited. Faced with an NGO that had predefined certain themes (gender, youth etc.), the journalists wanted subjects that were appropriate to the local needs, while giving each debate the value of national representation. As explained by a journalist from Citizen TV:

Sometimes we are asked to do these things. 'Go to Embu and talk about women's problems.' That never works! In Nyeri they would like us to speak only about the youth. You know, you can never go there and say that you would like to focus on the youth and politics. Then, we have to change some aspects. (...) In the first place, this programme has never been done before in the country. People want to talk; they want to say what their problems are. You can't go to a place and tell them 'This is what we would like you to talk about.' Then the people will tell you: 'We also have problems concerning A, B, C, D.' You cannot go to an area where there is no show, where you can say: ' $O k$, today, we were in Nyeri, where we spoke to the youth, yesterday we spoke about women so today, we will talk about schoolteachers, tomorrow we will talk about farmers! ${ }^{18}$

There were other conflicts that occurred, on the issue of invited speakers. An example is when the NGO invited Maina Kiai, chairman of the Kenya Human Rights Commission, particularly visible during the electoral campaign and highly critical of the Kibaki administration. The station was opposed to this, officially giving the reason that he was not on the list of expected speakers. ${ }^{19}$ In order to negotiate their editorial autonomy, the journalists fell back on the excuse of poor knowledge of the field and the expectations of Kenya viewers and on the argument of Media Focus' uselessness, as a "go-between" or "facilitator." The journalists sometimes went as far as to directly consult with UNDP.

However, some teams, such as that of Debate 07 on KTN, explicitly refused sponsorship despite offers that came their way. In the same manner, Hannington Gaya, the director of the Media Owners Association, refused to organise joint shows on all TV stations as had been the case in 2005 campaign:

This time around, I was very uneasy (...), I did not have the impression that it would be honest because some sponsoring bodies imposed rules: 'We would this like person 
to emcee the debate; we would like him to be like this.' (...) For example, the Republican Institute wanted only economic issues to be raised. For me, this meant that they wanted a pro-Kibaki campaign. Or: 'We would like so-and-so and so-and-so in the forum.' (...) They wanted to invite CEOs to ask the questions (...) gave me names of people to put in the forum..$^{20}$

\section{Spread and development of Western media models}

21 The Kenyan media are often influenced by Anglo-Saxon journalism models, ${ }^{21}$ at the level of separation between the "facts" and the "commentaries," the format of the shows, the daily news, and even jingles. The one of Citizen TV (This is Citizen) immediately draws images of CNN (This is CNN)... According to their designers, all political shows are inspired by British or American programmes. Examples are Debate 07 and Agenda Kenya. This former is the home-grown reply to the BBC's famous Question Time, which has been in existence since 1974 and practically became an institution in Great Britain. Debate 07 was created in September 2007 during the campaign period. It was presented by Linus Kaikai, a star presenter who aimed to reproduce the model of American electoral debates-initiated in the 1960s with the famous Nixon-Kennedy debate-which was not possible due to Kibaki's refusal to participate. Kaikai says that he is today inspired by the debates launched by CNN in partnership with YouTube.

It is worth noting that several presenters considering this type of debate as new in Kenya, claimed to be the source of this innovation, giving it an avant-garde role..$^{22}$ More interestingly, it can be seen that in the journalists' discussions, justification of this importation operates under the title of "democratic normalcy": Kenya, "a new democracy" opens up to media forms and "models" of democratic governance already in vogue in countries of the North. The challenge is thus on the image of Kenya and of Africa, that these journalists seek to portray. These broadcasts are in fact writings on the electoral campaign and the transition, an attempt to project an image of Kenya that is a "democratic window" of Africa (in a sort of nationalist enterprise), or an Africa where democracy is "normalised." ${ }^{23}$ For the journalists, it was a chance to display their "professionalism" and their public political power, to Kenyan politics and at international level. The fascination for the American media and more so during the elections (a reinforced effect by the parallel electoral agenda between the two countries), results from the feeling that the media "make" the election, especially through the contradictory debates between the candidates. ${ }^{24}$

Also to be examined are the importation phenomena through the careers of the journalists. The "importers" are actually deeply integrated in the media sphere, which occupies a dominant position in the field. With a strongly international reach (as seen in the studies done or by the awarding of prizes such as the BBC Africa Award etc.), they represent a model of success and of professional legitimacy. The prizes are especially valuable, if they are considered from the extroversion point of view of JeanFrançois Bayart, ${ }^{25}$ since they are reinvested in a particularly profitable manner within the country.

Finally, the remarkable presence of Western experts or "White wizards" as expressed by Vincent Hugeux, ${ }^{26}$ must be noted. Among these is the famous Dick Morris, former campaign manager and close ally of Bill Clinton, who "offered" his services to R. Odinga. ${ }^{27}$ Three weeks before the election, M. Kibaki also deferred to a foreign consultant, Marcus Courage, a Briton who had previously worked for him in 2002. ${ }^{28}$ 


\section{The Kenyan arena and political communication: professionalism and overlapping}

\section{Consultants}

of indigenous sector of political consultants with a growing recourse to journalists, NGOs, politicians and experts, so that a programme or communication strategy can be designed for a candidate or party; to design campaign priorities for the campaign of an $\mathrm{NGO}$, provide them with figures and analyses; or even to appear in the political shows as experts. A good illustration of the structure of a professional sector of experts during the campaign period remains the think tank, "Kibaki Tekelezi" (Kibaki must complete the work), ${ }^{29}$ partly constituted of Kenyan academics, which defined communication messages and strategies for M. Kibaki. These academics thus had a direct influence on the form that political shows on television would take, be in their own performance or through the advice in communication that they provided to the politicians and to journalists.

convergence with the political élite, collaboration with the NGO world and this visibility of university dons in the media reflects a specific strategy. Indeed, it allowed some dons to acquire celebrity status and to emphasise their intellectual authority, to spread ideas, justify a social usefulness, or simply to emerge from economic precariousness and thus rationalize an academic vocation. Inequalities in the world academic scene, difficult work conditions and very low salaries enticed several African academics to resort to consultancy, and not merely to propagate their ideas.

Although the example of these experts shows the interlocking between different fields, the specialisation of some actors in this sort of activity and their growing professionalism (creation of small consultancy companies, using most of their work hours doing this due to their lucrative nature) equally goes into autonomisation and harmonisation of professional practices linked to political communication and an indifference from the actors of the Academy. In this sense, their appearance in talkshows as experts is used as a means to demonstrate their knowledge, their value and acquire visibility with the aim of being employed by politicians. At this level, rather than demonstrations of loyalty, it is value-added impartiality that seems of greater impact in the consultant market. It allows them to keep their options open and to reinforce the argument of their authority and credibility, which is highly sought after by the politicians. ${ }^{30}$

Whereas the phenomenon of Kenyan spin doctors demands a more profound sociological analysis, two phenomena seemed interesting in relation to the profile of those that were interviewed-studies or foreign academic sojourns, long-term political vocation (this also shows the intermingling of politics/academia at the career level).

Another trend is the increase in the use of social sciences by politicians, through the use of various forms of expertise, notably demographics, in the constituencies. Finally, the "direct" use of researchers in the campaign trail, in relaying local opinion is quite fashionable. For the politicians, intellectual authority of the dons, their status as "national" figures due to their repeated appearance on TV, are good tools as they bring credibility to the programme and to the candidate.

Les Cahiers d'Afrique de l'Est / The East African Review, 38 | 2008 


\section{Strategies of political communication} communication tools during the campaign period. ${ }^{31}$ This was particularly the case for ODM, which had to compensate the shortcomings of their mobilisation by PNU, of resources and publics spaces (posters on public buildings etc.). It is in the media that ODM was seen and could benefit from equal airtime and speech in comparison to the presidential camp.

There was also the habitual use of posters, newspaper advertisements and even the use of cartoons. In 2007, there was also a flourishing use of SMS and spam (already having been used widely in 2002 and 2005) and additionally, calls on personal telephones: upon answering, the voter would find either R. Odinga or M. Kibaki on the other end. In reality, this was a voice recording of the candidate stating his campaign promises. ${ }^{32}$

Some politicians have also capitalised on the corruption of journalists. ${ }^{33}$ The government media, KBC and also those close to the authorities, for example Citizen TV, were placed under the influence of PNU, thus slanting the format of talk-shows, especially in the choice of invited guests. In 2005, the first edition of The Big Debate ${ }^{34}$ was harshly criticised by several observers: presented by Rose Kimotho, director of Radio Kameme and an ally of M. Kibaki, she was clearly in the pro-Banana camp. In 2007, during the talk-shows broadcast by private stations, pressure from the government was less visible. Nevertheless, the difficulties experienced by M. Kiai in appearing on the guest forum of Louis Otieno Live... gives an indication of the degree of pressure that could be weighed on the media during the campaign. ${ }^{35}$

The large presence of journalists in the campaign teams should be noted; they were often hired as experts in political communication just like the university dons, but also as press attachés. M. Kibaki, for example, turned to the services of the former CEO of the Nation

Media Group, Wilfred Kiboro. ${ }^{36}$ But it is ODM that took up several journalists, having characteristically taken a relatively important place in the field but also having had a taste of disillusionment in the 2002 changes, especially in litigation cases such as David Makali, former Managing Editor of The Standard.

Concerning talk-shows, it is worth observing that in the case of Louis Otieno Live. the venue of a show in a region became a political stake, especially for the parliamentary candidates, but also in the civic elections (many candidates in the civic elections were part of the audience). The edition of Louis Otieno Live. in Narok was quite remarkable in this sense: some candidates who were not invited by the producers spontaneously showed up to be part of the forum. The symbolic resources that the candidates hoped to get from these broadcasts were major-television is supposed to confer credibility and political weight, as well as surpassing one's local ambitions, as it is a medium with a rational reach.

\section{Professionalisation of the public in talk-shows}

36 Another interesting phenomenon in the analysis of structuring the field of political communication in Kenya is the professionalisation of the actors present in audience of these shows. Some activists from different political parties were specifically "mandated" by the Secretariat to appear in the audience of the talk-shows, so that they 
would play the role of party representatives. According to a PNU "representative," there were about ten of them, ${ }^{37}$ chosen by the head of communications within the secretariat..$^{38}$ They participated in several talk-shows during the campaign, thus providing them an opportunity to fine-tune their skills in public speaking and to increase their own visibility (some of these representatives were candidates in the civic elections).

This phenomenon is a means of recruiting members of the public by the producers of the shows and is not limited to political parties. The producers specifically assigned to "public mobilisation" often united in service research actually turned to a kind of indirect mobilisation through associations, political parties, and community groups, that they contacted and charged with the task of providing audience members. There is thus a wealth of choice to select from for representation in audiences. The control of the media on public speech is therefore relative, as the filtration process is done by these organisations. It is at this level that a "professionalisation" of the audience of talk-shows is done, and they become new "personalities" in political communication, acquiring televisual skills and thus capital, which they can reinvest. ${ }^{39}$ Generally speaking, there was a huge social homogenity in the audience of these shows. Out of about 40 people interviewed on Louis Otieno Live... from 13 December in Nairobi, 20 were senior graduates (universities, colleges, technical institutes). Among the others, three had been to secondary school. 11 stated that they had no academic qualifications. The largest number, 33, claimed to belong to a political party or an association. ${ }^{40}$

The televised image of the "ordinary citizen" complex selection process of the people seen in the studio, in which there is call for spontaneous candidates, party and association delegates and a network of interpersonal knowledge of journalists.

Some shows were the direct choice of a representation. Where journalists were could be clearly seen in the interviews, the public's contribution was more ambiguous, as the value added to the broadcast remained the idea of confrontation between the "leader" and the "citizens." As explained by L. Kaikai:

We specially assigned tasks [to some members of the audience], to ask specific questions. We had human rights, political reform, women's issues, corruption. We asked these people who had a background in the subject to ask these questions. That is why we had a director of an anti-corruption NGO to ask questions on corruption, we had a women's leader who raised gender-based issues. (...) These people represented something, the majority of whom were recognizable as they regularly appeared in the media. When a comment on corruption was needed, they knew what to say and viewers were familiar with their faces. They were always involved in public debate. This was an opportunity to bring together both candidates and "experts." 42

In a show like Debate 07, the producers wanted to create equality between the public and the guest speakers. When R. Odinga came to the studio on 19 December, some of the audience had even been coached by the KTN team.

41 In Crossfire, the Sunday radio talk-show of Kiss FM, the twenty or so people attending the show are also mostly from the upper middle class, holding academic professions. Once again, due to the mobilisation process of the public, who in this case were on the interpersonal list but certainly also due to the show's format, when a new "out-ofstudio" formula was required to "bring political debate to the people," a show was held at the New Stanley Hotel. This is a five-star hotel in Nairobi, complete not only with 
tourists, leather armchairs and colonial décor, but also with valets and bodyguardsthus acting as a sort of dissuasion to the participation of the "common man" who would note dare set foot into the hotel.

This was a strategic choice by the producers. According to them, restricting the discussion to intellectual level was more efficient than popular speech. ${ }^{43}$, in view of speeches by political leaders. From this we see the constitution of public personalities who took on a double status through these shows as they were highly present in the media and could be invited to a forum (as leaders) and in the public (as ordinary citizens). This ambiguity is well summarised in the vague definition of the "civil society." For example, in this ambiguous category is the director of Cradle, a local NGO, who is also a woman- rights activist having participated in the Bomas constitution reform process, and is an advocate of the Law Society of Kenya.

A majority of the people in the audience often had prior experience (albeit different) in speaking in public. They sometimes had responsibilities or political and social involvements. Their appearance at this sort of show often follows a precise agenda: the promotion of a cause, publicity for an organization or party, the search for an audience and exposure. Some appeared mainly in civic elections, an experience which could improve oratory qualities and help in building networks ${ }^{44}$

The political communication sector in Kenya is thus structured along lines of exclusion of some actors, to the benefit of "professionals," despite a lively discussion on direct democracy and popular participation.

\section{The moral and political model projected in the talk- shows}

45 After having seen the structure of the political communication sphere in Kenya, it is easier to understand the model of the moral and political order observed in the political shows on television. This order declines in interaction models between those led and their leaders, in citizenship and leadership models, and in creating a national ideal.

Contrary to what the violence at the beginning of 2008 would make one think and contrary to some incitation to hate observed in local radio talk-shows on stations such as Kass FM (Kalenjin), Inooro (Kikuyu) and Radio Lake Victoria (Luo) ${ }^{45}$, the political debate on national stations reflected and increased a sort of moralization of public debate, according to well-defined values.

Media coverage of the campaign was generally equal and attentive to suggestions from the candidates, to verbal outbursts and fraud attempts. Opinion polls took centre stage, and human rights defenders were clearly on the scene. Nevertheless, some shows went further than a simple equitable coverage of the debates by proposing a normative model of democratic negotiation, citizen participation and national community by taking tribalism as the first target. 


\section{The reconstruction of a democratic order, the "rationalisation" of politics}

\section{Pluralist representations: accuracy and balance} identification, on which the idea of pluralism also rests. In order to perfect the idea of staging national debates, making the shows credible and due to the predominant issues of redistribution and marginalisation, the producers persisted in recreating a representation of some form of regional diversity (and thus tribal), along with religious and professional diversity. This shows a reconstitution and celebration of a Kenyan nation, reinvented and famous for its diversity, and the establishing of equality in access to speech and political representation. This was symbolized by equal access to the media. According to the producers, equitable identification was respected through specific attention to the profiles of the people invited to form the audience. In promotional speech on these shows, the members of the public were meant to represent the man on the ground, the common man. They became some type of "major voters" or "delegates" representing the different groups composing the Kenyan nation, no matter their appearance (sex, veil, Maasai attire) or by the cause that they represented (women, Islam, farmers, matatu touts).

In the case of the mobile shows, the value of national representation was even further brought to the limelight. For the journalists, the show was not simply an opportunity to 
discuss a subject. It was a moment for consultation and integration with certain populations in the national debate. This led to insistence on their part when stating the rules of the debate, that participants should speak in their capacity as "inhabitants" of Isiolo, Nyeri, or Embu. It is with this idea in mind that some journalists bypassed the topics defined by their donors, to avoid restricting the residents of a constituency to particular themes and to offer them an opportunity to make their demands known at national level.

\section{Adding value to the citizen's personal responsibility}

Despite this "community" aspect, it was striking to observe the importance accorded to the figure or the scale of the individual in the shows. Generally speaking, the NGOs involved in electoral education programmes insisted during the campaign period on the responsibility of the electors in choosing a representative. ${ }^{50}$ However, this specific insistence on the individual's political responsibility, be it at the level of the vote or at the level of taking centre stage in the talk shows, should also be put in relation to the rejection of tribalism. Taking the example of the format of the talk shows, the instructions given by the presenter of a show held in Narok were very clear, focusing on the particularity of the show as a performance venue of a re-moralised political order. In Narok, L. Otieno introduced his debate as follows:

We are here as individuals, not to reduce the Maasai issue to what you hear outside. You are not obliged to share our point of view. What you have is an identification card and a voter's card. Therefore if someone raises an opinion that you do not agree with, it does not mean that you must believe what he believes. ${ }^{51}$

The idea was to detribalise the competition for power, to focus on rhetoric, and to discourage ethnic loyalty in the voting process. This was to forewarn about bitter reactions after the results and to promote an idea of politics based on a choice considered as beneficial to the entire country and also as being more "rational," less given to identification passions, with a Cartesian ideal of an individual enlightened due to a freedom from ethnic belonging. This idea of rationality has the tendency to associate the idea of ethnic allegiance to the irrational, while this same step more often revealed the hope of economic repercussions and thus of a choice that should be carefully considered.

\section{Focusing on problems rather than on candidates}

Parallel to this specific attention to personal political responsibility, the talk shows also had a rule to reject discussions on people and individuals, such as giving an assessment or critique of actions or of the personality of a politician.

This example leads us to the third characteristic of the model, the ideal of an issuebased campaign. This terminology in itself comes from political communication experts in the United States. ${ }^{52}$ Issue based is opposed to horse-race or game based coverage. In Kenya, thanks to this principle, the idea still encounters tribalism and detaches the stakes of the election from ethnic identity, to add value to trans-ethnic issues, on which the debates focused.

57 The issue-based ideal has important implications on the list of journalistic criticisms by depreciating direct criticism of a leader or candidate and by modifying the conditions of confrontation with the leaders. On the other hand, although the majority of the 
producers have kept the desire to launch oppositional debate, the idea is not to make the opposition less dramatic (with statements such as: "After all, we are all Kenyans"; "If your neighbour has a different opinion it's not a big deal"), but to seek solutions and points of agreement, and to have a strong propositional side. The candidates had larges blocks of time to expose their programmes. On the other hand, some sought to deport from the list of criticisms from time to time and to bring forward positive aspects of the political situation. Louis Otieno Live. recorded in Isiolo, for example, was begun by the presenter in the following words: "I would like us to start with the positive things in Isiolo, of the things that are going well."

\section{Making politics a science: the role of experts}

These talk shows are also a narration of a performance of political "normalcy" and "rationality" of the country, which corresponds to the expectations of the alternation of 2002 as time for democratic normalcy in Kenya.

For this, the experts (cited earlier) played a key role. Some openly sought to change the rules of the political game to make it more professional, make it a science, make political competition a rational and calculable affair of which they would have the key. Hence, for Isaac Otieno, consultant:

The idea of professional politics only gained ground in 2002. Because in 2002 people like me began to be employed to only work on politics it became profitable and professional. Thirdly, working exclusively on politics came to be seen as a scientific activity. Thus in 2002, we tried it out and realised that it worked very well and that it led to NARC's success. ${ }^{53}$

Whereas political representations as a science may have permeated into the electoral field, they also entered the media through the presence of experts on television. In this case as well, it is tribalism that was targeted as these experts had a desire to restore political competition on the field of economic and social expertise, to evaluate the programmes and actions of the leaders, and to focus the debate on the priorities defined as a result of scientific expertise.

61 They also took part in a valorising the recentralisation of a choice of leader on his personal ability by developing modules of advice on communication and in political marketing (even if the facts of this advice in political marketing obviously exploits political potential in redistribution networks, including tribal). The scientific aspect of politics is also veered against the invisible, religious invocation and the various components of charismatic power (especially in "politics of the stomach," sorcery, money etc., and relationships), with the desire to explain and expose how the leaders got to their positions, to take political competition to the field of science and thus remove the sacred aura of power. As indicated in the extract of the interview with I. Otieno below, television is (probably paradoxically) meant to take part in this desacralisation, via strictly followed rules on the screen and the exposure of candidates to questions from the participants.

There is popular representation in Kenya which sees politics in itself as a dirty and nasty thing. This is true of the people who want to access power in order to steal money, people who want power to control, dominate and dictate behaviour. And when they see us speaking here, they see that politics is actually a harmless profession. That politics is scientific! We are speaking here of science in the media, we use figures, we talk of programmes, we raise questions on how measures are put in place, we bring out a political economy in decision-making in the country, a 
political economy of violence, a political economy of corruption, which is a huge problem in the country ... And then they see us, they can look at us, watch us on TV and can therefore say: 'These are normal people! They are harmless. ${ }^{54}$

\section{Agitating for social peace through the media} journalists project in the talk shows. With these broadcasts, one sees a process of "civilisation of political exchange" according to the values that have been restored and resulting from strict regulations on the screen. Beyond a simple balanced coverage of the campaign, Kenyan journalists have sought to influence the form and depth of electoral debate, to "moralise" political exchange. This attitude was again found in the attitude of the media, including the press, after the beginning of the violence, with a clear and shared position on the level of coverage of the confrontations and the position to take concerning suspicions of fraud. ${ }^{55}$ The political communication sphere in Kenya is thus additionally structured around these norms and the "moral mission" of the media.

Journalists and NGOs also made a bet on the "ritual of boxed reversal," as described by James Scott. ${ }^{56}$ This means that in a dynamic similar to that of celebrations or fairy tales that show a reversal of power, these talk shows as the stage for democracy will play a cathartic role, and have an effect in the "real" world of politics by defusing political anger and recourse to violence: the expression of demands and the playing the role of citizen allowed for an absorption of frustration and release of pressure, which J. Scott refers to as "the valve theory." This theory must be considered with precaution and not be systematised, as this sort of ritual can represent a "preparation" rather than an "alternative" to the reversal. ${ }^{57}$

Another aspect of the performance project is that of an equalisation of the participants, characteristic of the myth of a communication society, which draws from the idea of a model of an egalitarian society network. ${ }^{58}$ The inequalities of the facts presented in the Kenyan society are supposed to disappear in the model of debate staged in the talk shows, even if they resurface as inequalities in access to speech in the shows and in equalities in oral capacities etc. Once again in the terminology of James Scott, the "public manuscript" of the show would be equality, and the "hidden manuscript" would be inequalities. He illustrates this by giving the example of an academic seminar, an example that can be very well applied to televised talk shows:

The public manuscript desires that all those around the table be endowed with the same power, and this is what is encouraged in the architectural form of this kind of meeting. However (...) the distribution of power has absolutely nothing to do with equality; despite this, it is impossible to bring this out explicitly and directly during the seminar. ${ }^{59}$

This reinvention of social conditions in the national debate, the detachment from the ground as earlier expressed, is also due to this performance characteristic and the projection of an idealised political arena. 


\section{The variables of the set}

\section{Self-presentation and imaginary citizenship in public intervention} the case even where the key questions varied: "Inclusion and Nationhood"; "Leadership and Development" etc. To understand this phenomenon, several factors must be taken into account: first, as earlier seen, the question of the topic to be covered was a result of negotiations between the donor (who preferred to have other more transversal themes such as the youth and women) and the editorial team. The former wanted to localise the debate, making it relevant to issues on, the ground to the point where the moderator placed specific emphasis on the notion of community (Kamba, Maasai etc.) This was in order to place the show in the role of political intermediary between the centre and the periphery or grassroots, which were strongly integrated in the discussions of the journalists within the general elections process. It amounted to justifying political utility with a political (placing the media at the centre of Kenyan political space) commercial aim.

70 In this show, the contributions of the "citizens" were homogenous. They first put value on the land (Kambaland is a place of "milk and honey," Maasai Mara is "one of the wonders of the world," "we are sitting on gold, and we do not know it," etc.) and at the same time, they also spoke about the poverty of the area (no roads, dependence on food handouts, no education, etc.). Another notable point is the importance of the discussions of "self-mobilisation," with injunctions such as "we must mobilise ourselves [to emerge from poverty], no one will do it for us," etc. However, the most poignant characteristic was the often-brutal criticism of local leaders who did not ensure redistribution. This criticism and focusing of debate on the local challenges partly 
explains the direction of the debate by the presenter, as well as on electoral deadlines and the huge presence of politicians among the audience. These latter used this as an opportunity to put forth their legitimacy as leaders, and to campaign. ${ }^{60}$ This factor was a hijacking of the recommendation for an issue-based campaign.

71 In all the shows, the leaders were actually at the centre of reproach-corruption, alienation from the grassroots, non-consideration of problems of poverty and underdevelopment, with a particular focus on issues of responsibility to citizens, whom they were supposed to serve. On this point, the use of "we" or of "me" opposed to "you" or "them" is enough of an indication and reinforcement of the idea of a homogenous community of voters. In Agenda Kenya, a contributor stated:

You politicians have created this culture [of vote-buying]. We are going to have a politician who will come to give us money because it is a culture that you have created. No politician must give me money! ${ }^{61}$

Generally, these shows displayed a strong scepticism, or anger directed at those elected and the political élite. It was striking to note that in this edition of Agenda Kenya on financing political parties, the applause was mainly for those who were neutral: a university don presented as a governance and public policy consultant, and a former vice-chairman of the ECK, who had both proclaimed their partisan neutrality at the beginning of the show. These two people took highly critical positions concerning the use of money during the campaign.

The text messages sent during Agenda Kenya and in Louis Otieno Live... were homogenised and classified into two categories: "yes" and "no," in response to a question asked at the beginning of the broadcast, ${ }^{62}$ therefore leaving out the accompanying comments. However, those sent to the radio broadcast Crossfire confirmed the use of this type of channel to express disillusion or anger towards the political élite, in language that was often more crude and direct than that on live discussions on the screen. Below are a few examples taken from Crossfire, on 9 December 2007.63

We have thieves and corrupt people across the political divide, we are waiting for all of them to die, and leave us to ourselves

Corruption is corruption-let people like Maanzo [chairman of ODM-K] not speak of corruption because he received bribes and a vehicle in order to make Hon Raila group separate from his party ODM-K

Kenyans are overtaxed to pay the same MPs who have stolen billions and hide abroad

I read the list on the Stupidity Index every Saturday in the Nation. I think that some of these parties belong to this group, especially PNU in collaborating with all the Mois, Biwotts and Pattnis ${ }^{64}$ of the world. It speaks volumes that ODM is part of this absurdity with the likes of Moi in its ranks (...)

In Louis Otieno Live..., self-introductions centred on the affirmation of one's right to speak "as a citizen," "as a Kenyan," and the value of his representative role, be it gender, generation, religion or ethnic community or even party: "I want to speak for the women of this country/district," "as a student...," "I'm a member of the League of Kenyan women voters," "as a supporter of PNU," etc. Although this phenomenon was quite visible in Agenda Kenya, the majority of the participants only gave their last and first name, or went directly to the question, which correspond to the model of the detribalised and individualised image of the voter. In the issues of Agenda Kenya watched, ethnic references in self-introductions were absent, even though belonging to an area (designated in non-ethnic forms like "the people of Molo," "someone from Garissa") is valorised in an idea of authenticity of the experience shared by the contributor. 
the names of the names of ethnic groups are used to identify oneself and not the Other. This means that in a broadcast done in Kitui, the word "Kamba" or "Ukambani" will feature prominently, together with expressions like "the people of Kitui," "our community," "this community," "the people of this region," "we." Nevertheless, the designation of the Other systematically goes through roundabout means: "People from other regions," "so-called mainstream communities," "other communities," "some ethnic groups," "the right ethnic group" (in describing ethnic groups that enjoy the fruits of redistribution), "neglected communities," "pastoral communities," "minorities." The identification of the Other by the name of its ethnic group therefore remains very rare on television and leads to a list of unspeakable terms on television, without this necessarily being linked to the rules stated at the beginning of the show.

\section{The unspeakable and variations in identity}

79 Contributions of members of the public are not always appropriate to the expected model. The most usual example of going beyond the boundaries of the unspeakable is found in what journalists call the "personalisation of the debate." However, this blameworthy personalisation must also operate within a certain format. It was notable that during the broadcast of Louis Otieno Live.in Narok, attacks against Wole Ntimama (harsh and clearly directed against him through qualifications such as "the leadership of Parliament in Narok North") were not cut short by the journalist, despite the strong instruction to base the debate on issues and not on personalities according to the model. Nevertheless, the journalist very quickly stopped a nominative contribution:

If Mzee Ntimama can do nothing to influence the government, I would like to know what he is doing there. Do not misunderstand us-it is only that Mzee Ntimama has been a Minister of State for a long time. He claims to have an influence on cabinet 
decisions now, but not on, those that concern the development of Narok! He is simply tired, he must retire to his home!

ethnicized one, party affiliation also had the tendency to be set in the talk shows due to the means of recruiting members of the audience. The life tales of the participants show elements of complex political loyalties, constantly shifting and winding, within which lies ethnic, generational, ideological and gender aspects The analysis of talkshows in the electoral campaign in Kenya shows how much the producers of these shows, journalists, NGOs and experts, wanted to see the shows as a moralisation tool for political life in Kenya and to fight against tribalism. The producers therefore fronted an idealised debate, incarnated by the "professionalized" middle-classes, in a configuration that masked inequalities, giving an impression of detachment from the ground and a framework of public speech. The voluntarism seen was to anchor the campaign thematically and to detach the voting process from ethnic loyalties but it collided with the regional homogeneity of the results. However, the Kenyan media in general and the talk-shows in particular participated in spreading demands for transparency from political leaders (associated to their direct presence on television before the public), demands for citizens to speak out and a notion of political balance, as seen in the national television stations in marginalised areas and by the partisan and identification equilibrium recreated in the public. 
This analysis provides for a better understanding of the attitude of the media during the crisis that followed the voting process. The journalists indeed adopted a common position in calling for peace and choosing not to take sides on the question of election fraud, or even to lead an investigation on the subject. This amounted censoring some information on the violence, due to threats by the government on freedom of expression but also for fear of being part of the conflagration and fixation on identification rancour.

Kenyan journalists acted prudently faced with the urgency for a return to calm and under pressure from the State. On 30 December, the government went so far as to place a ban, on audiovisual media giving live broadcasts. The journalists rejected this ban. Kiss FM continued to emit live news, and the Media Council, under W. Waruru expressed the profession's collective refusal to bend to this ban. However, apart from Kiss FM, this measure ended up being applied to some extent. ${ }^{67}$ Despite having been a performing model of detribalised debate, talk-shows disappeared from television screens. On 29 January, KTN and the Media Institute, an organisation headed by David Makali, deposed a complaint against this ban, which was eventually lifted on 4 February.

The attitude of the press during the crisis was linked to this interdiction and was also in continuity with the desire to battle against ethnic divisions. This editorial choice of responsibility on the part of Kenyan journalists corresponds to the list of criticisms and control of the media by the government, also translated into a mutation of the code of ethics that reflected and encouraged talk-shows in Kenya today.

\section{BIBLIOGRAPHY}

BAYART, J.-F. (1997). L'Illusion identitaire. Paris: Fayard.

BOURDIEU, P. (1984). 'Quelques propriétés des champs.' Questions de sociologie. Paris: Les éditions de Minuit.

BRISSET-FOUCAULT, F. (2005). Une anti-chambre des députés. Prise de parole, politisation et pratique citoyenne dans les talk shows radiophoniques de Kampala, mémoire de DEA de science politique, sous la direction de Richard Banégas, Université Paris 1 Panthéon-Sorbonne.

DEZALAY, Y., GARTH, B. (2002). La mondialisation des guerres de palais. Paris: Seuil.

GERSTLE, J. (2004). La communication politique. Paris: Dalloz/A. Colin.

GUILHOT, N. (2004). 'Une vocation philanthropique. George Soros, les sciences sociales et la régulation du marché mondial.' Actes de la Recherche en Sciences Sociales, no. 151-152, pp. 37-48.

HUGEUX, V. (2007). Les sorciers blancs. Enquête sur les faux amis français de l'Afrique. Paris: Fayard.

LIVINGSTONE, S., LUNT, P. (1994). Talk on television. Audience participation and public debate.

London, New York: Routledge.

NEVEU, E. (2006). Une société de communication? Paris: Montchrestien, (4 édition).

Les Cahiers d'Afrique de l'Est / The East African Review, 38 | 2008 
RAMBAUD, B. (à paraître). 'Réflexions sur les trajectoires africaines des modèles médiatiques occidentaux.' In D. DARBON (ed.), Modèles, fabrication et usages de modèles dans l'analyse des Afriques de la mondialisation, actes du colloque éponyme du 4 février 2006, Bordeaux, Maison des sciences de l'homme d'Aquitaine (MSHA).

SCOTT, J.C. (été 2006). 'Infra-politique des groupes subalternes.' Vacarme, no. 36.

\section{NOTES}

1. NTV is owned by Nation Media Group, whose majority owner is the AgaKhan while KTN of The Standard Group is three-thirds owned by Daniel arap Moi's family.

2. The figures on the number of Kenyans who own a television set varies according to the various sources as no nationwide survey has benn carried out on this subject. However, in order to give an idea of the size, it is useful to indicate that it oscillates between $17 \%$ and $32 \%$. One must take into account the fact that even if many Kenyans do not own a set, they watch TV in public places, particularly in bars. See Africa Media Development Initiative, BBC for figures: http://downloads.bbc.co.uk/worldservice/ trust/pdf/AMDI/kenya/amdi_kenya6_television.pdf_archive].

3. Counted and presented as graphic opinion polls at the end of each programme.

4. 'The Elusive Live Debate.' The Standard, 11 December 2007.

5. According to the Washington Post, the campaign expenses of the two main parties varied between 6 to 10 million US dollars. See Stephanie McCrummen, 'Kenya Tests New Style of Politicking.' Washington Post, 22 December 2007. In comparison, in France, the campaign of the Socialist Party (PS) or the Union for a Popular Movement (UMP) in 2007 cost each of the two parties about 20 million euros. Nevertheless, there is is some vagueness concerning the fundng of political parties and camapigns in Kenya, and some of the funds are personally raised by the candidates, bypassing their political party. For more on this, see the inquiry by Coalition for Accountable Political Financing, http://capf.or.ke/default.asp [not available. Archive].

6. This was intially a failure as the first show was presented by Rose Kimotho, the owner of Radio Kameme, suspected to be a close ally of M. Kibaki and "pro-banana." After this, the producers decided to leave the presentation of the Big Debate to L. Otieno and J. Gichuru.

7. P. Bourdieu, 1984.

8. For an analysis of these dynamics in the French context, see J. Gerstlé, 2004, p. 138.

9. N. Guilhot, 2004.

10. Y. Dezalay and B. Garth, 2002.

11. Only two examples will be given here. However, it should be noted that the Centre for Multiparty Democracy (CMD) also sponsored broadcasts on the state- owned station, $\mathrm{KBC}$ and that the Republican Institute sought to sponsor programmes in partnership with the Media Owners Association. The former is part of National Endowment for Democracy (NED), and its office is headed by John McCain, Republican presidential candidate in the USA.

12. To the point that some media have refused sponsorship offers, to the benefit of others. 
13. In 2006, the Nation Media Group's annual turnover had increased by $13 \%$ as compared to the previous year and attained Ksh 6.3 billion. The pre-tax profit reached Ksh 1.2 billion. See http://www.nationmedia.com/corporate/images/ Nation_Annual_Report.pdf [not available].

14. A TV station claiming to be ' $100 \%$ Kenyan.' $\mathrm{K} 24$, was launched this year.

15. The dependence choices are further contrasted: journalists of the radio programme Crossfire preferred to be sponsored by the mobile telephone company Celtel than by an $\mathrm{NGO}$, considering that the former allowed them editorial autonomy.

16. The last edition of Louis Otieno Live on the Road was not sponsored by Media Focus.

17. This sponsorship was seen by some journalists as an interference in a show that was popular before the arrival of sponsors within a team that had been created several months earlier. This explains the difference with Agenda Kenya, which had not held this type of debate since the editorial work was more separated between the NGO and the station. The fact that Media Focus is an NGO of the North could have added to the malaise by incorporating dependence relationships. The relationship between Medeva and NTV was stated as a 'businness' one rather than a 'development' one.

18. Interview with a journalist from Citizen TV, Nairobi, 24 December 2007.

19. This example also suggests the influence of political pressure or self-censorship in the format of the talk-shows.

20. Interview with Hannington Gaya, 19 December 2007.

21. For more on the issues of spread and reappropriation of French and Anglo- Saxon models of journalism in Africa, see the works of B. Rambaud (forthcoming).

22. This was not always true. Interview with L. Kaikai, Nairobi, 19 December 2007, interview with L. Otieno, Nairobi, 24 December 2007.

23. This statement of normalcy, of Kenya as a 'model' or 'exception' on the continent, has been highly present in the media since 2002. It was again displayed during the January 2008 crisis, in the expressions of surprise incomprehension shown by the journalists. For an analysis of media coverage of the crisis, see the article by B. Rambaud in this issue.

24. The adaptation of these models to the Kenyan context and their eventual modification by the protagonists demands a comparative study treated with the American or British shows which inspired them. According to the journalists interviewed, the modifications are essentially technical and are independent of their wish (for example the presidential debate which did not happen and would have had to be transformed into individualised auditions of K. Musoyka and R. Odinga). It will be rather interesing to see if such a problem of ethnic representation exists in the public arena in Great Britain and in the United States.

25. "Extroversion consists of embracing foreign cultural elements by submitting them to local objectives" (J.-F. Bayart, 1997, p. 80).

26. This phenomenon is also present in francophone Africa and is described by Hugeux in his book. The profile of the consultants and the conditions in which they are employed by African leaders seem to be different in anglophone Africa. See Vincent Hugeux (2007), for a comparison.

27. Bill Clinton's campaign manager in 1996, he resigned two months before the election after a scandal involving a prostitute. Since then, he has been an editorial 
writer, a consultant and often appears in talk-shows in the US. During the Kenyan campaign, Morris was expelled for the country on the grounds that he did not have a work permit, but he continued to work for ODM from the States (Nairobi Star, 8 December 2007). Raila Odinga and Morris maintained that they did not have a commercial arrangement and that the American had offered his services for free.

28. Courage is a marketer who heads an enterprise called Africa Practice. It encourages the IDE and political communication of international organisations in Africa. He also worked for the campaign of the new Nigerian president, Umaru Yar'Adua.

29. http://www.taifatekelezi.com [not available. Archive].

30. To give an idea of the rates in this profession, a consultant confirmed that he demands Ksh 100,000 (1,000 euros) for communication advice and developing parlaimentary campaign messages in Nairobi and about Ksh 8,000 (80 euros) for an advice session with a civic election candidate.

31. It should be specified that a recourse to vote-buying had greatly developed. According to the Coalition for Accountable Political Financing, a regrouping of NGOs financed by the USAID. An average of Ksh 5 million was distributed to constituencies during the party nominations held in 2007. The NGO comprises Transparency International and the Center for Multiparty Democracy among others. The survey also revealed that $38 \%$ of the candidates' campaign budget was set aside for vote-buying (http://capf.or.ke/default.asp [Not available. Archive]).

32. Some actors did not remain at SMS level: Safaricom offered an information service in real time, especially during the broadcast of the results (Ksh 7 per SMS), just like the Nation Media Group did.

33. Interview with a journalist from The Standard, Nairobi, 10 December 2007.

34. See Joe Kadhi, 'How the referendum was covered.' 11 February 2007, http:// mediawatchman.blogspot.com [Archive].

35. For an in-depth anaylsis on the inequalities of coverage between the candidates on the different stations, refer to the study carried out by Strategic Africa for the UNDP, available on www.strategicafrica.com.

36. 'Kibaki's Muthaiga club.' New Vision, 22 December 2007.

37. Interview with a PNU activist, participant in Louis Otieno Live, Nairobi, 24 December 2007.

38. According to the PNU activist, these representatives received neither reimbursements for costs incurred or an allowance for their task, as would have been the case in local mobilisation operations or to attend a meeting.

39. In the talk-shows viewed in Nairobi, the members of the public received an allowance or per diem varying from Ksh 100 to 1,000, depending on the distance travelled (some came from provinces very far from Nairobi) and had to spend the night there.

40. These figures came from questionnaires distributed by this researcher to the audience of talk-shows.

41. For an analysis of the importance of this figure in the myth of a coomunicatiion society, see E. Neveu, 2006, p. 52-55.

42. Interview with L. Kaikai, Nairobi, 19 December 2007. 
43. This was especially so on television. A strong division in roles is clear in the journalists' discussions. Radio is perceived as the media for the masses and television for the élite, who, according to L. Kaikai, correspond to the 'second level of the exercice power.' For him, television is an opportunity to place leaders face-to-face with their equals, where they would be in a position to challenge the intellectuals. This choice also works for the targeted public: television being perceived by these journalists as an élite media, they prefer to stage élites.

44. In response to the question: "What kind of value can the show bring to you?" in the questionnaire distributed to participants in the talk-shows viewed, some people answers were along the lines of "Boost my political ambitions" or "Mature my political status," etc.

45. IRIN, 'Kenya: spreading the word of hate.' 22 January 2008, http:// www.irinnews.org/Report.aspx?ReportId=76346. [Not available. Archive]. These differences can be, among others, due to the aims of the different radio station owners, often allied to some politicians, or a result of the profile of the talk-show presenters, but it reveals a systematic planning of violence by the directors of the radio station. See Jamal Abdi and James Dean, 'The Kenyan 2007 elections and their aftermath: the role of media and communication.' BBC World Service Trust, March 2008, p. 9 et 10.

46. "To maintain a fair balance at all levels of time allocation on air between the different points of view. Allocation of air time on free blocks was done in consultation with the ECK during the campaign period preceding presidential, parliamentary or local elections. This allowed the political parties participating in the elections, to present their policies." http:// www.kenyalaw.org/kenyalaw/klr_app/frames.php [Not_available. Archive].

47. This does not mean that partisan equity was respected on KBC: even if attention to the small candidates was greater on private stations, media coverage was unbalanced as it was highly skewed towards the outgoing president.

48. And also a function of the political pressure that they were subjected to.

49. Interview with Omweri Angima, CMD, Nairobi, 18 December 2007.

50. The ECK funded the deployment of huge posters in Nairobi with messages such as "do not complain about corruption if you ae not gong to vote," or even "do not complain about unemployment," etc.

51. Luis Otieno Live..., Narok, December 2007.

52. J. Gerstlé, 2004, pp. 132-136.

53. Interview with avec Isaac Otieno, consultant, Nairobi, 14 December 2007.

54. Interview with I. Otieno, op. cit.

55. See the analysis of B. Rambaud in this volume for more on this point.

56. J.C. Scott, 2006, 'Infra-politique des groupes subalternes,' Vacarme no. 36. https:// doi.org/10.3917/vaca.036.0025.

57. For a study of the effects of regular participation in talk-shows on individual careers and entry into politics, see F. Brisset-Foucault (2005), pp. 211-232.

58. E. Neveu, 2006.

59. Interview with J.C. Scott, 'Dans le dos du pouvoir.' Vacarme, no. 42, Winter 2008, p. 9. https://doi.org/10.3917/vaca.042.0004. 
60. This was strikingly so in Narok, where the show turned into appraisal of William ole Ntimama's mandate.

61. Agenda Kenya, ‘Political financing,' December 2007.

62. For example: 'Should political parties disclose the source of the fundings?' (Agenda Kenya, 'Political Financing,' December 2007) or 'Are elected leaders responsible for development?' (Louis Otieno Live... 'Leadership and Development,' Kitui, December 2007).

63. According to the producer of the show, several hundred SMS were received at each edition. At the end of the show, these were printed out and given to the guest speakers, who each chose two or three to air. In the shows viewed, an average of seven text messages were read. Those cited here were not necessarily aired. They are reproduced here verbatim. "We have thieves $n$ corrupt people acrose the political divide, we are waiting 4 all of them 2 die, we are helpless"; "Corruption is coruption let people like Maanzo not talk about corruption because him he was bribed in order and given a vehicle in order to frustrate Hon Raila group from his party ODM-K"; "Kenyans are being overtaxed to pay the same MPs who stole billions \& are keeping abroad"; "I read the stupidity indew column every sat [urday] in the nation. I think this parties belong to this group n particularly PNU with collaboration the mois biwotts patnis of this world. It speaks wolumes that ODM is party 2 this nonsense with mois remnants in its ranks (...)."

64. The former president Daniel arap Moi, Nicholas Biwott, or the "Total Man," one of the main figures in political repression under Moi's regime, Kamlesh Pattni, one of the protagonists of the Goldenberg scandal of the 1990s.

65. S. Livingstone, 1994.

66. Interview with a PNU activist, member of the audience in Louis Otieno Live, Nairobi, 24 December 2007.

67. An exemption was made for the opening of the Parliamentary Session on 15 January.

\section{AUTHOR}

\section{FLORENCE BRISSET-FOUCAULT}

The author is a PhD candidate in Political Science at the University of Paris 1 PanthéonSorbonne. 